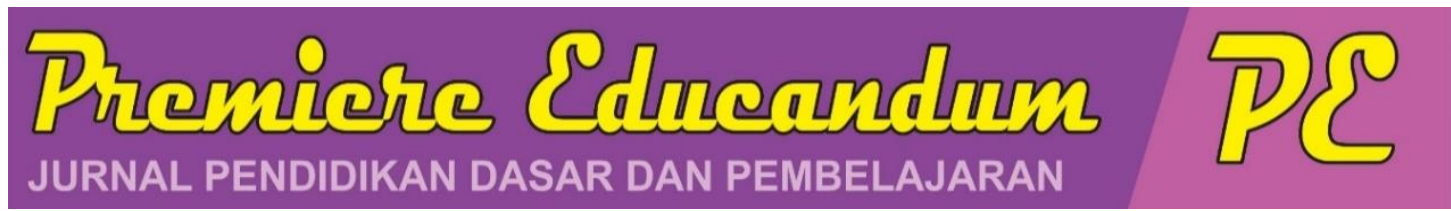

Premiere Educandum: Jurnal Pendidikan Dasar dan Pembelajaran

Volume 9 (2) 203 - 213 Desember 2019

Copyright C2019 Universitas PGRI Madiun

ISSN: 2088-5350 (Print) / ISSN: 2528-5173 (Online)

Available at: http://e-journal.unipma.ac.id/index.php/PE

Doi: $10.25273 /$ pe.v9i2.5234

\title{
Pengembangan aplikasi android berbentuk education games berbasis budaya lokal untuk keterampilan membaca permulaan bagi siswa kelas 1 SD/MI
}

\author{
Giri Indra Kharisma ${ }^{1}$, Faizal Arvianto ${ }^{2)}$ \\ ${ }^{1}$ Fakultas Ilmu Pendidikan, Universitas Timor \\ 1 email: indrakharisma@unimor.ac.id \\ ${ }^{2}$ Fakultas IImu Pendidikan, Universitas Timor \\ 2email: faizal_arvianto@yahoo.com
}

\begin{abstract}
Reading at the beginning in first grade students of Islamic elementary school must be concern to the children world that relates to their gaming activity. Education games becomes good solution in combining learning and gaming activity so it can train thinking, speaking ability, and children's soft and hard motoric. Choosing kind of games used in learning eventually should be suitable to technology and science development without disregarding local culture sustainability. This research aims at developing product such as android application of education games based on local culture of NTT in reading at the beginning comprehension of the students. Design model of this research and development is modification of R2D2 by Willis and ASSURE from Heinich and friends. Based on that modification, it can be gotten research procedure that consist of three primary activities, they are definition, design planner and developing process and dissemination. Assessment result from expert in Indonesian leaning of elementary school, learning media, and practitioner mention that application product in good developed is implemented because it gets score percentage more than $75 \%$. Limited trial result conducted to twenty eight students in the first grade of TTU Islamic elementary school shows that this learning application product is suitable to be implemented because of score percentage more than $85 \%$.
\end{abstract}

Keywords: reading at the beginning, education game, learning application

\begin{abstract}
Abstrak
Pembelajaran membaca permulaan pada siswa kelas 1 SD/MI harus sesuai dengan dunia anak yang lekat dengan kegiatan bermain. Education games menjadi solusi yang tepat dalam menggabungkan kegiatan belajar dan bermain sehingga dapat melatih kemampuan berfikir, berbahasa, serta melatih motorik halus dan motorik kasar anak. Pemilihan jenis permainan yang nantinya digunakan dalam pembelajaran harus disesuaikan dengan perkembangan ilmu pengetahuan dan teknologi tanpa melupakan kelestarian budaya lokal. Penelitian ini bertujuan untuk mengembangkan produk berupa aplikasi android berbentuk education games berbasis budaya lokal Nusa Tenggara Timur untuk keterampilan membaca permulaan bagi siswa kelas 1 SD/MI. Model desain penelitian dan pengembangan ini merupakan modifikasi dari R2D2 milik Willis dan ASSURE dari Heinich, dkk. Dari hasil modifikasi tersebut, diperoleh prosedur penelitian yang terdiri atas 3 kegiatan utama yakni tahap pendefinisian, tahap perancangan desain dan pengembangan, serta tahap desiminasi. Hasil penilaian dari ahli pembelajaran bahasa Indonesia SD, ahli media pembelajaran, dan praktisi menyebut bahwa produk aplikasi yang dikembangkan layak diimplementasikan karena memperoleh persentase skor lebih dari 75\%. Hasil uji coba terbatas yang dilakukan kepada 28 siswa kelas 1 MIN Timor Tengah Utara juga menunjukkan bahwa produk aplikasi pembelajaran ini layak untuk diimplementasikan karena memperoleh persentase nilai lebih dari $85 \%$.
\end{abstract}

Kata Kunci: membaca permulaan, permainan edukasi, aplikasi pembelajaran

Histori artikel : disubmit pada 10 Oktober 2019; direvisi pada 09 Desember 2019; diterima pada 09 Desember 2019 


\section{A. PENDAHULUAN}

Membaca merupakan keterampilan berbahasa yang bersifat reseptif karena memperoleh informasi melalui media tulis. Membaca tidak hanya sekadar mengenal dan melafalkan lambang bunyi, tetapi juga perlu memahami isi bacaan. Menurut Adhim (2004:12), membaca merupakan proses yang kompleks dan fundamental karena kemampuan membaca menjadi dasar untuk mengembangkan kemampuan yang lain. Dengan membaca, anak dapat mempelajari berbagai bidang ilmu sehingga dapat dikatakan bahwa kunci keberhasilan anak dalam kegiatan belajar di masa depan terletak pada kemampuan membacanya (Hasanudin \& Puspita, 2017). Mengingat begitu pentingnya keterampilan membaca, banyak orang tua yang mengajari keterampilan membaca kepada anaknya sejak usia dini.

Keterampilan membaca pada siswa kelas $1 \mathrm{MI} / \mathrm{SD}$ termasuk ke dalam membaca permulaan. Membaca permulaan merupakan suatu proses keterampilan dan kognitif (Aulina, 2016). Proses keterampilan menunjuk pada pengenalan dan penguasaan lambang-lambang fonem, sedangkan proses kognitif menunjuk pada penggunaan lambang-lambang fonem yang sudah dikenal untuk memahami makna suatu kata atau kalimat (Rahim, 2008:32). Tahapan membaca permulaan dititikberatkan pada kesesuaian antara tulisan dan bunyi yang ada, kelancaran dan kejelasan suara, dan pemahaman isi atau makna (JOBAR, 2003). Persiapan membaca didukung dengan pengalaman keaksaraan seperti membaca buku atau sering menggunakan tulisan maupun simbol saat pembelajaran. Bahan-bahan untuk membaca permulaan harus sesuai dengan bahasa dan pengalaman anak.

Pembelajaran membaca permulaan pada anak harus sesuai dengan dunia anak yang lekat dengan kegiatan bermain. Education games menjadi solusi yang tepat dalam menggabungkan kegiatan belajar dan bermain (Ramansyah, 2015). Education games (permainan edukatif) merupakan suatu kegiatan yang sangat menyenangkan dan dapat dijadikan cara atau alat dalam mendidik. Education games adalah permainan yang mengandung unsur mendidik yang dirancang dan dibuat untuk merangsang daya pikir anak dan melatih memecahkan masalah (Herman, Saleh, \& Islami, 2017). Masuknya game dalam proses belajar melahirkan suasana yang menyenangkan karena anak dapat mengendalikan kecepatan belajar sesuai dengan kemampuannya. Pengaruh education games pada anak diantaranya dapat melatih kemampuan berfikir serta kemampuan berbahasa anak. Selain itu, education games dapat melatih motorik halus dan motorik kasar anak (Fithri \& Setiawan, 2017).

Pemilihan jenis permainan yang nantinya digunakan dalam pembelajaran harus disesuaikan dengan perkembangan ilmu pengetahuan dan teknologi. Hal ini sesuai dengan tuntutan kurikulum 2013 yang menekankan penggunaan teknologi informasi dan komunikasi dalam dunia pendidikan (Amirullah \& Hardinata, 2017). Ditambah lagi, perkembangan teknologi di bidang informasi dan telekomunikasi mengalami perkembangan pesat, khususnya di Indonesia. Berbagai perangkat telekomunikasi, khususnya smartphone 
dan tablet, tersebar di seluruh Indonesia. Pertiwi (2019) menuliskan bahwa badan riset pasar Canalys mencatat sepanjang 2018, pertumbuhan pengapalan smartphone di Indonesia mencapai 17,1 persen dibanding tahun 2017. Jumlah smartphone yang dikapalkan di tanah air selama tahun 2018 mencapai 38 juta. Sementara pada kuartal IV-2018, jumlah pengiriman smartphone mencapai $\quad 9,5$ juta unit, naik 8,6 persen secara yearon-year (YoY). Berdasarkan data tersebut, maka dapat diprediksi bahwa teknologi telekomunikasi, khususnya smartphone dan tablet, masih akan menjadi primadona yang terus berkembang dari tahun ke tahun.

Seiring berkembangnya teknologi informasi dan komunikasi di era modernisasi ini, muncul tantangan dalam melestarikan budaya lokal. Budaya lokal yang identik dengan sifat tradisional acapkali tidak mampu bertahan dalam arus modernisasi (Gunanto, 2018). Parahnya, ada pandangan masyarakat yang beranggapan bahwa budaya lokal adalah budaya primitif, sehingga menjadikan masyarakat alergi dengannya. Pandangan seperti ini tentu akan mempercepat punahnya kebudayaan yang sebenarnya sarat akan nilai. Oleh karena itu, upaya-upaya untuk melestarikan budaya lokal perlu dirancang dan dilaksanakan dalam berbagai bentuk, salah satunya dengan mengintegrasikannya ke dalam aktivitas pembelajaran di sekolah (Suyitno, 2017).

Pemaparan argumen di atas
menjadi landasan untuk
mengembangkan produk berupa aplikasi
android berbentuk education games

berbasis budaya lokal untuk keterampilan membaca permulaan. Permainan edukasi yang dikembangkan dalam penelitian ini berbentuk aplikasi android yang dapat diakses melalui smartphone atau tablet. Aplikasi ini nantinya dijadikan sebagai media pembelajaran dalam pembelajaran membaca lanjutan di sekolah. Pada aplikasi ini akan disajikan materi melafalkan abjad, membaca suku kata dan kata. Materi tersebut dikemas dalam bentuk permainan, seperti mencocokkan suku kata, mencocokkan gambar, menirukan suara, dll. Berdasarkan karakteristiknya, Aplikasi ini juga tergolong ke dalam mobile learning karena dapat diakses melalui perangkat mobile serta dapat digunakan kapanpun dan dimanapun. Aplikasi ini dibuat hanya berfungsi sebagai komplemen (pelengkap), artinya aplikasi diprogram untuk melengkapi materi pembelajaran yang diterima siswa di dalam kelas. Hal ini dikarenakan, penelitian ini tetap memandang bahwa pembelajaran melalui tatap muka tetaplah penting.

Penelitian tentang aplikasi android pernah dilakukan oleh Mohammad Arif Fadli dengan judul Pengembangan Aplikasi Mobile Learning Berbasis Smartphone Android untuk Pelajaran Bahasa Inggris Pokok Bahasan Recount Text (2013,skripsi). Penelitian tersebut menghasilkan produk berupa aplikasi bernama "Mari Belajar: Recount Text". Dari penelitian tersebut, diperoleh hasil uji kelayakan yakni $93,4 \%$ untuk ahli media, 90\% untuk ahli materi, 95,5\% untuk untuk siswa kelompok kecil, dan $87,1 \%$ untuk siswa secara keseluruhan. Hasil penelitian menyebutkan bahwa media pembelajaran yang dikembangkan oleh Mohammad Arif 
Fadli masih terdapat beberapa kekurangan yakni: ukuran huruf dan tombol yang digunakan terlalu kecil, tampilan yang kurang menarik, dan menu navigasi yang masih menyulitkan siswa dalam mengoperasikannya.

Penelitian yang sama juga pernah dilakukan oleh Herman, Sirajuddin, \& Islami dengan judul Penerapan Media Aplikasi Education Games Berbasis Budaya Lokal untuk Meningkatkan Kemampuan Membaca Permulaan pada Anak di Taman Kanak-Kanak (2017). Aplikasi yang digunakan berbentuk aplikasi macromediaflash 8.0. dari penelitian tersebut diperoleh hasil dari siklus I menunjukkan hanya ada dua anak yang berada pada kategori berkembang sangat baik, sisanya masih banyak anak yang berada di rentang bawah rata-rata. Namun, saat siklus II, terdapat peningkatan hasil belajar yang sangat baik. Hal ini terlihat dari hampir semua anak berada pada kategori berkembang sangat baik.

\section{B. METODE PENELITIAN}

Model desain penelitian dan pengembangan yang digunakan dalam penelitian ini diadaptasi dari desain R2D2 (Reflective, Recursive, Design, and Development) dari Willis dan desain ASSURE (Analyze learner characteristics, State objective, Select or modify media, Utilize, Require learner response, and Evaluate) dari Heinich, dkk. Desain R2D2 dan ASSURE dimodifikasi sesuai dengan kebutuhan dalam penelitian dan pengembangan ini. Keenam tahapan pada desain ASSURE dikelompokkan ke dalam 3 fokus pengembangan pada desain R2D2 (Kharisma, 2019). Dari hasil modifikasi tersebut, maka didapat prosedur penelitian dan pengembangan yang terdiri atas 3 kegiatan utama yakni tahap pendefinisian, tahap perancangan desain dan pengembangan, serta tahap desiminasi.

Fokus pendefinisian meliputi kegiatan (1) menganalisis karakteristik umum kelompok sasaran dan (2) menyatakan atau merumuskan tujuan pembelajaran. Kedua kegiatan tersebut dilakukan dengan cara analisis kelas, telaah kurikulum, dan telaah teori. Hasil telaah tersebut digunakan untuk menyusun spesifikasi produk yang akan dikembangkan.

Tahap perancangan desain dan pengembangan berisi kegiatan mengembangkan materi dan media yang tepat. Awalnya, peneliti mengumpulkan bahan dasar yang dibutuhkan untuk mengembangkan produk berdasarkan spesifikasi yang telah dirancang pada tahap sebelumnya. Setelah perancangan desain, barulah dilakukan fokus pengembangan dengan melakukan penyusunan produk dari semua bahan yang telah disiapkan. Program yang digunakan dalam menyusun produk yakni iSpring Suite 9, website 2 APK builder, dan Java7.

Prototipe produk yang telah jadi kemudian diujicobakan dan dimintai tanggapan dari ahli pembelajaran bahasa Indonesia sekolah dasar, ahli media pembelajaran, praktisi (guru kelas), dan siswa kelas 1A MI Negeri Timor Tengah Utara yang berjumlah 28 orang. Tanggapan tersebut nantinya digunakan oleh peneliti dalam merevisi produk sebelum disebarluaskan.

Tahap desiminasi merupakan tahap penyebarluasan produk. Produk yang sudah selesai direvisi kemudian 
disebarluaskan melalui internet dan dapat diunduh secara gratis.

Data dalam penelitian ini berupa data verbal dan numeral. Data verbal pada tahap prapengembangan diperoleh dari hasil wawancara dan observasi yang ditujukan kepada guru dan siswa. Data verbal pada tahap uji coba produk berupa komentar, kritik, dan saran dari ahli dan praktisi yang terdapat dalam angket validasi. Data verbal pada tahap uji kelas/lapangan berupa catatan hasil observasi terhadap respon, reaksi, dan komentar siswa mengenai prototipe produk yang telah dicoba. Sementara itu, data numeral diperoleh dari hasil penilaian ahli, praktisi dan hasil observasi.

Pada tahap pendefinisian, teknik pengumpulan data yang digunakan yakni observasi dan wawancara terbuka kepada guru kelas dan beberapa siswa kelas 1 MIN TTU. Observasi dilakukan untuk mengetahui karakteristik siswa dan kemampuan siswa dalam menggunakan smartphone. Dari hasil observasi diketahui bahwa siswa MI/SD kelas 1 senang bermain, memiliki rasa ingin tahu yang tinggi, dan ingin terlibat aktif dalam pembelajaran. Selain itu, siswa MI/SD kelas 1 juga sudah mampu mengoperasikan smartphone secara dasar, seperti menghidupmatikan smartphone, membesarkecilkan suara, memilih aplikasi, dan keluar dari aplikasi. Wawancara kepada guru kelas 1 MIN TTU dilakukan untuk mengetahui penggunaan media pembelajaran untuk materi membaca permulaan. Dari hasil wawancara tersebut, diketahui bahwa guru hanya menggunakan buku teks dalam menyampaikan materi karena keterbatasan fasilitas dan pengetahuan teknologi. Selain itu, wawacanara juga dilakukan kepada siswa kelas 1 untuk mengetahui fungsi smartphone di kalangan siswa. Hasilnya, rata-rata siswa menggunakan smartphone untuk bermain game dan menonton youtube.

Pada tahap uji ahli, teknik pengumpulan data yang digunakan yakni angket (kuesioner) untuk memperoleh data verbal dan numeral. Angket validasi produk diberikan kepada ahli pembelajaran bahasa Indonesia sekolah dasar, ahli media pembelajaran, dan praktisi sebagai pedoman dalam memberikan penilaian terhadap produk yang dikembangkan.

Pada tahap uji coba produk, teknik pengumpulan data yang digunakan yakni observasi. Teknik ini digunakan untuk mengetahui respon, reaksi, dan komentar siswa saat menggunakan prototipe aplikasi pembelajaran. Dari teknik ini diperoleh data numeral dan data verbal.

Teknik analisis data pada penelitian ini dilakukan dengan teknik kualitatif dan kuantitatif. Analisis data kualitatif dibagi menjadi tiga, yakni (1) analisis data studi pendahuluan (identifikasi), (2) analisis data uji ahli dan praktisi, dan (3) analisis data uji coba kepada subjek uji coba. Teknik analisis kuantitatif digunakan untuk menganalisis data kuantitatif yang diperoleh dari angket penilaian. Hasil data kuantitatif dihitung dengan rumus kuantitatif sederhana berikut ini

$$
\mathrm{P}=\frac{\sum x}{\sum x i} \times 100 \%
$$

Keterangan:

$\mathrm{P}=$ Prosentase 


$$
\begin{aligned}
\sum x= & \text { Jumlah keseluruhan } \\
& \text { jawaban responden dalam } \\
& \text { seluruh item } \\
= & \text { Jumlah keseluruhan skor } \\
& \text { maksimum dalam satu item } \\
\sum x i= & \text { Konstanta }
\end{aligned}
$$

Nilai hasil data responden kemudian diinterpretasikan sesuai dengan pedoman yang ada pada tabel di bawah ini.

Tabel 1. Pedoman Interpretasi Kualitas Media Pembelajaran

\begin{tabular}{ccc}
\hline Persentase & Kualifikasi & Tindak Lanjut \\
\hline $85 \%-100 \%$ & $\begin{array}{c}\text { Sangat } \\
\text { layak }\end{array}$ & Implementasi \\
\hline $75 \%-84 \%$ & Layak & $\begin{array}{c}\text { Implementasi } \\
\text { dengan sedikit } \\
\text { revisi }\end{array}$ \\
\hline $55 \%-74 \%$ & $\begin{array}{c}\text { Cukup } \\
\text { layak }\end{array}$ & $\begin{array}{c}\text { Revisi sesuai } \\
\text { catatan ahli dan } \\
\text { praktisi }\end{array}$ \\
\hline$<55 \%$ & $\begin{array}{c}\text { Kurang } \\
\text { layak }\end{array}$ & $\begin{array}{c}\text { Revisi dengan } \\
\text { pengubahan }\end{array}$ \\
\hline & (dikutip dari Sugiyono, 2010)
\end{tabular}

\section{HASIL DAN PEMBAHASAN Deskripsi Produk}

Produk yang dikembangkan pada penelitian ini adalah aplikasi android berbentuk permainan edukasi berbasis budaya lokal untuk pembelajaran membaca permulaan pada siswa kelas 1 SD/MI. Aplikasi ini dapat diakses pada smartphone atau tablet berbasis android sehingga siswa dapat belajar secara mandiri dimanapun dan kapanpun. Melalui aplikasi ini, belajar membaca akan lebih menyenangkan sehingga menambah minat dan motivasi siswa. Selain itu, siswa juga dapat mengatur kecepatan belajarnya sesuai dengan kemampuannya.

Aplikasi pembelajaran ini digunakan dalam mata pelajaran bahasa
Indonesia untuk siswa kelas $1 \mathrm{MI} / \mathrm{SD}$ dengan materi membaca permulaan. Melalui aplikasi ini, siswa diajak untuk belajar membaca kosa kata yang berisi nama-nama benda yang ada di lingkungan sekitar siswa. Adapun kompetensi dasar yang menjadi landasannya yakni Kompentesi Dasar 3.6 Menguraikan kosakata tentang berbagai jenis benda di lingkungan sekitar melalui teks pendek (berupa gambar, slogan sederhana, tulisan, dan/atau syair lagu) dan/atau eksplorasi lingkungan.

Aplikasi pembelajaran ini dikembangkan dengan model education games. Artinya, aplikasi tersebut berisi materi pelajaran yang dikemas dalam bentuk permainan. Jenis permainan yang digunakan dalam aplikasi ini terdiri atas: 1) melengkapi suku kata; 2) mencari suku kata; 3) melengkapi kata; dan 4) mencocokkan gambar. Permainan melengkapi suku kata berisi kegiatan mencocokkan huruf atau suku kata agar menjadi suku kata yang sesuai dengan contoh. Permainan mencari suku kata berisi kegiatan menyimak suku kata. Siswa diminta menyimak suku kata kemudian memilih jawaban yang sesuai dengan suku kata yang telah disimak. Adapun permainan melengkapi kata berisi kegiatan melengkapi kata yang rumpang dengan cara memilih suku kata yang tepat. Permainan mencocokkan gambar melatih siswa untuk mencocokkan gambar dengan nama yang sesuai. Dalam aplikasi pembelajaran ini, apabila jawaban siswa benar, maka akan muncul icon centang dan siswa dapat melanjutkan ke soal berikutnya. Apabila jawaban siswa salah, muncul icon silang dan siswa wajib memilih jawaban yang lain. 
Gambar 4.1 merupakan tampilan dari setiap jenis permainan yang ada pada aplikasi Berlatih Membaca.
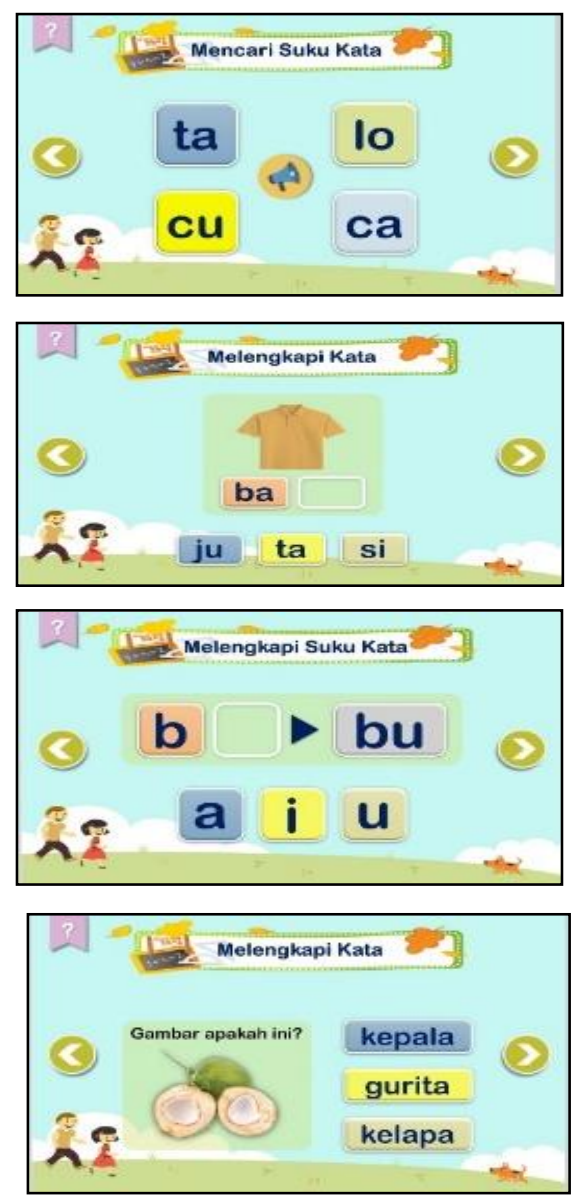

Gambar 1. Jenis Permainan dalam Aplikasi Pembelajaran

Aplikasi pembelajaran ini juga menampilkan beberapa kebudayaan lokal Nusa Tenggara Timur sebagai bahan materi membaca. Adapun budaya lokal yang dipilih berupa makanan tradisional, bangunan tradisional, alat musik tradisional, permainan tradisional, dan hewan endemic provinsi NTT. Dari kebudayaan lokal yang ditampilkan, beberapa di antaranya sering dijumpai oleh siswa sehingga mudah dikenali seperti makanan, permainan, dan hewan asli NTT. Berikut daftar kata dari kebudayaan lokal NTT yang disajikan dalam produk aplikasi pembelajaran.

Tabel 2. Daftar Kata dalam Kebudayaan Lokal Nusa Tenggara Timur

\begin{tabular}{ll}
\multicolumn{1}{c}{$\begin{array}{c}\text { Bentuk } \\
\text { Kebudayaan } \\
\text { Lokal }\end{array}$} & \multicolumn{1}{c}{ Daftar Kata } \\
\hline Nama makanan & $\begin{array}{l}\text { madu, kolo, salome, sei, } \\
\text { cucur, sirih, pinang }\end{array}$ \\
\hline Nama alat music & $\begin{array}{l}\text { Moko, sowito, nuren, } \\
\text { mendut, sasando, suling }\end{array}$ \\
\hline Nama & $\begin{array}{l}\text { Sikidoka, gotrio, } \\
\text { kartupel, patpoto, } \\
\text { permainan }\end{array}$ \\
\hline Nama bangunan & Lopo, musalaku, gereja \\
\hline Nama hewan & Komodo, kakatua \\
\hline Nama tanaman & cendana \\
\hline Lain-lain & Bemo, nona \\
\hline
\end{tabular}

Aplikasi pembelajaran ini terdiri atas dua aplikasi yakni Belajar Membaca dan Berlatih Membaca. Kedua aplikasi tersebut memiliki isi dan tujuan yang berbeda. Aplikasi Belajar Membaca berisi materi mengenal huruf, membaca suku kata, dan membaca kata. Pada aplikasi tersebut juga dilengkapi dengan suara sehingga siswa dapat mengetahui cara pelafalan huruf dan membaca suku kata hingga kata dengan benar. Setiap kata yang ditampilkan dalam aplikasi juga dilengkapi dengan gambar yang menarik demi menambah minat belajar siswa. Adapun aplikasi Berlatih Membaca berisi soal-soal latihan untuk mengetahui kemampuan membaca siswa setelah menggunakan aplikasi Belajar Membaca. Soal latihan tersebut disajikan dalam bentuk permainan yang sederhana tetapi menyenangkan. Untuk penjelasan lengkap tentang isi dari masing-masing menu pada setiap aplikasi dapat dilihat pada Tabel 3 dan Tabel 4. 
Tabel 3. Isi Menu pada Aplikasi Belajar Membaca

\begin{tabular}{|c|c|}
\hline \multicolumn{2}{|c|}{ Aplikasi Belajar Membaca } \\
\hline Menu Utama & Keterangan \\
\hline Info & $\begin{array}{l}\text { Berisi penjelasan singkat } \\
\text { tentang isi aplikasi. }\end{array}$ \\
\hline $\begin{array}{l}\text { Mengenal } \\
\text { Huruf }\end{array}$ & $\begin{array}{l}\text { Berisi daftar huruf dan cara } \\
\text { melafalkannya }\end{array}$ \\
\hline $\begin{array}{c}\text { Membaca } \\
\text { 1-4 Suku Kata }\end{array}$ & $\begin{array}{l}\text { Berisi cara membaca suku } \\
\text { kata dan kata yang terdiri } \\
\text { dari 2-4 suku kata. Suku kata } \\
\text { yang dimaksud yakni suku } \\
\text { kata yang tidak diakhiri } \\
\text { dengan huruf konsonan, } \\
\text { seperti: ba-tu, ka-ki, } \\
\text { ko-mo-do, ma-ta-ha-ri, dll. }\end{array}$ \\
\hline $\begin{array}{l}\text { Suku Kata } \\
\text { Berakhiran } \\
\text { Konsonan }\end{array}$ & $\begin{array}{l}\text { Berisi cara membaca suku } \\
\text { kata dan kata yang terdiri } \\
\text { dari 2-3 suku kata. Suku kata } \\
\text { yang dimaksud yakni suku } \\
\text { kata yang diakhiri dengan } \\
\text { huruf konsonan, seperti: } \\
\underline{\text { ban-tal, } \text { - }-\underline{\text { kor }}} \\
\underline{\text { cen-da-na, pe-sa-wat, dll. }}\end{array}$ \\
\hline $\begin{array}{l}\text { Membaca } \\
\text { 'ng' dan 'ny' }\end{array}$ & $\begin{array}{l}\text { Berisi cara membaca suku } \\
\text { kata dan kata yang } \\
\text { berakhiran atau mengandung } \\
\text { unsur 'ng' dan 'ny' }\end{array}$ \\
\hline
\end{tabular}

Tabel 4. Isi Menu pada Aplikasi Berlatih Membaca

\begin{tabular}{|c|c|}
\hline \multicolumn{2}{|c|}{ Aplikasi Berlatih Membaca } \\
\hline Menu Utama & Keterangan \\
\hline Info & $\begin{array}{l}\text { Berisi penjelasan singkat } \\
\text { tentang isi aplikasi. }\end{array}$ \\
\hline $\begin{array}{l}\text { Melengkapi } \\
\text { Suku Kata }\end{array}$ & $\begin{array}{l}\text { berisi kegiatan mencocokkan } \\
\text { huruf atau suku kata agar } \\
\text { menjadi suku kata yang } \\
\text { sesuai dengan contoh. }\end{array}$ \\
\hline $\begin{array}{l}\text { Mencari Suku } \\
\text { Kata }\end{array}$ & $\begin{array}{l}\text { berisi kegiatan menyimak } \\
\text { suku kata. Siswa diminta } \\
\text { menyimak suku kata } \\
\text { kemudian memilih jawaban } \\
\text { yang sesuai dengan suku } \\
\text { kata yang telah disimak. }\end{array}$ \\
\hline $\begin{array}{l}\text { Melengkapi } \\
\text { Kata }\end{array}$ & $\begin{array}{l}\text { berisi kegiatan melengkapi } \\
\text { kata yang rumpang dengan } \\
\text { cara memilih suku kata yang } \\
\text { tepat. }\end{array}$ \\
\hline $\begin{array}{c}\text { Mencocokkan } \\
\text { Gambar }\end{array}$ & $\begin{array}{l}\text { mencocokkan gambar } \\
\text { dengan nama yang sesuai. }\end{array}$ \\
\hline
\end{tabular}

\section{Data Hasil Uji Ahli dan Praktisi}

Pada tahap uji ahli dan praktisi, data numeral dan verbal diperoleh dari hasil penilaian ahli dan praktisi terhadap produk aplikasi pembelajaran. Data tersebut terdapat pada angket yang telah diberikan. Pada angket tersebut terdapat tujuh aspek yang terdiri atas: (1) isi media, (2) struktur materi, (3) evaluasi, (4) sistematika penyajian, penggunaan bahasa, (6) penggunaan suara \& tampilan, dan (7) efisiensi. Berikut merupakan data hasil penilaian dari ahli dan praktisi yang tampak pada Tabel 5.

Tabel 5. Data Numeral dari Ahli dan Praktisi

\begin{tabular}{|c|c|c|c|c|c|c|}
\hline Aspek & A1 & A2 & $\mathbf{P}$ & $\begin{array}{l}\text { Total } \\
\text { Skor }\end{array}$ & $\begin{array}{l}\text { Persen- } \\
\text { tase }\end{array}$ & Ket \\
\hline Isi media & 26 & 28 & 28 & 82 & $85,4 \%$ & I \\
\hline $\begin{array}{l}\text { Struktur } \\
\text { materi }\end{array}$ & 8 & 10 & 11 & 29 & $80,5 \%$ & $\mathrm{I} / \mathrm{R}$ \\
\hline Evaluasi & 7 & 6 & 8 & 21 & $87,50 \%$ & I \\
\hline $\begin{array}{l}\text { Sistematika } \\
\text { penyajian }\end{array}$ & 6 & 7 & 8 & 21 & $87,50 \%$ & I \\
\hline $\begin{array}{l}\text { Penggunaan } \\
\text { bahasa }\end{array}$ & 13 & 15 & 13 & 41 & $85 \%$ & I \\
\hline $\begin{array}{l}\text { Suara dan } \\
\text { tampilan }\end{array}$ & 24 & 25 & 23 & 72 & $85,71 \%$ & I \\
\hline Efisiensi & 18 & 22 & 22 & 62 & $86,11 \%$ & I \\
\hline
\end{tabular}

Keterangan:

Al : Ahli Pembelajaran Bahasa Indonesia SD

A1 : Ahli media pembelajaran

$P \quad$ : Praktisi

$I \quad$ : Implementasi $R$

:Revisi

Berdasarkan tabel 4, dapat diketahui bahwa ketujuh aspek pada produk aplikasi pembelajaran layak diimplementasikan karena memperoleh persentase lebih dari 75\%. Namun, untuk aspek struktur materi perlu sedikit revisi sesuai dengan masukan ahli pembelajaran bahasa Indonesia SD. Ahli pembelajaran menyebut bahwa terdapat contoh kata pada aplikasi 
pembelajaran yang tidak sesuai dengan kompetensi dasar sehingga perlu dihapus.

Selain data numeral yang telah dipaparkan dalam Tabel 4, juga terdapat data verbal yang dihimpun berdasarkan komentar dan saran dari ahli maupun praktisi. Komentar dan saran juga diperoleh secara tertulis melalui angket penilaian yang telah diberikan kepada ahli dan praktisi. Adapun data verbal tersebut disajikan pada Tabel 6.

Tabel 6. Data Verbal dari Ahli dan Praktisi

\begin{tabular}{ll}
\hline \multirow{2}{*}{ Sumber } & \multicolumn{1}{c}{\begin{tabular}{c}
\multicolumn{1}{c}{ Komentar dan Saran dari } \\
Ahlin Praktisi
\end{tabular}} \\
\hline & $\begin{array}{l}\text { Kompetensi Inti, Kompetensi } \\
\text { Dasar, indikator, dan materi } \\
\text { sudah sesuai. }\end{array}$ \\
\cline { 2 - 2 } & $\begin{array}{l}\text { Beberapa contoh tidak sesuai } \\
\text { dengan materi, misalnya pada } \\
\text { materi suku kata berakhiran } \\
\text { huruf konsonan. }\end{array}$ \\
\cline { 2 - 2 } & $\begin{array}{l}\text { Keterangan pada latihan } \\
\text { mencocokkan gambar tidak }\end{array}$ \\
& sesuai \\
\cline { 2 - 2 } & $\begin{array}{l}\text { Aplikasi mudah digunakan dan } \\
\text { pemilihan materi sudah sesuai } \\
\text { dengan tingkat perkembangan } \\
\text { siswa sekolah dasar. }\end{array}$ \\
\hline & $\begin{array}{l}\text { Latihan yang terdapat pada } \\
\text { aplikasi sudah interaktif. }\end{array}$ \\
\cline { 2 - 2 } $\begin{array}{l}\text { Penggunaan bahasa sudah baik } \\
\text { dan sesuai dengan karakteristik } \\
\text { siswa }\end{array}$ \\
\hline $\begin{array}{l}\text { Perlu tambahan icon untuk } \\
\text { kembali ke menu awal pada } \\
\text { aplikasi berlatih membaca jika } \\
\text { memang diperlukan. Ikon (?) } \\
\text { sebaiknya dimanfaatkan. }\end{array}$ \\
\hline
\end{tabular}

\section{Keterangan:}

A1 : Ahli Pembelajaran Bahasa Indonesia SD A1 : Ahli media pembelajaran

\section{Data Hasil Uji Kelas Terbatas}

Uji kelas terbatas dilakukan di kelas IA MI Negeri Timor Tengah Utara dengan jumlah siswa 28 orang. Data hasil uji kelas diperoleh melalui teknik observasi yang dilakukan oleh dua orang. Observasi dilakukan ketika siswa belajar membaca menggunakan aplikasi Belajar Membaca dan Berlatih Membaca. Selama kegiatan tersebut berlangsung, observer mengamati tanggapan, reaksi, dan komentar siswa terhadap aplikasi tersebut. Terdapat empat aspek yang diamati oleh observer, yakni: 1) isi media, 2) penggunaan bahasa, 3) penggunaan audiovisual, dan 4) efisiensi. Adapun data dari hasil observasi tersebut disajikan pada Tabel 7.

Tabel 7. Data Hasil Observasi Kelas

\begin{tabular}{cccc}
\hline Aspek & Skor & Persentase & Ket. \\
\hline $\begin{array}{c}\text { Isi } \\
\text { media }\end{array}$ & 28 & $87,5 \%$ & Implementasi \\
\hline Bahasa & 8 & $100 \%$ & Implementasi \\
\hline $\begin{array}{c}\text { Suara } \\
\text { dan } \\
\text { tampilan }\end{array}$ & 42 & $87,5 \%$ & Implementasi \\
\hline Efisiensi & 15 & $93,7 \%$ & Implementasi \\
\hline
\end{tabular}

Berdasarkan hasil observasi yang tampak pada tabel 6, dapat diketahui bahwa keempat aspek memperoleh persentase lebih dari $85 \%$. Hal tersebut menunjukkan bahwa produk aplikasi pembelajaran yang diujicobakan kepada siswa kelas 1A MIN TTU layak diimplementasikan.

\section{Revisi Produk}

Revisi produk dilakukan berdasarkan nilai persentase yang didapat dari hasil penilaian ahli dan praktisi. Berdasarkan hasil penilaian tersebut, aspek struktur materi masuk kategori layak diimplementasikan dengan sedikit revisi. Hal tersebut didasarkan pada perolehan persentase skor yang berjumlah 80,56\%. Dalam melakukan revisi produk, komentar atau saran dari ahli dan praktisi perlu 
dipertimbangkan sesuai dengan spesifikasi produk aplikasi pembelajaran.

Aspek struktur materi pada aplikasi pembelajaran memperoleh komentar dari ahli dan praktisi. Mereka menyebut bahwa terdapat beberapa contoh kata yang tidak sesuai dengan kompetensi dasar 3.6. Contoh kata tersebut dianggap tidak berada di lingkungan sekitar siswa. Berdasarkan komentar tersebut, maka perbaikan dilakukan dengan cara menghapus contoh kata yang dimaksud oleh ahli dan praktisi, seperti yang tampak pada Gambar 2.

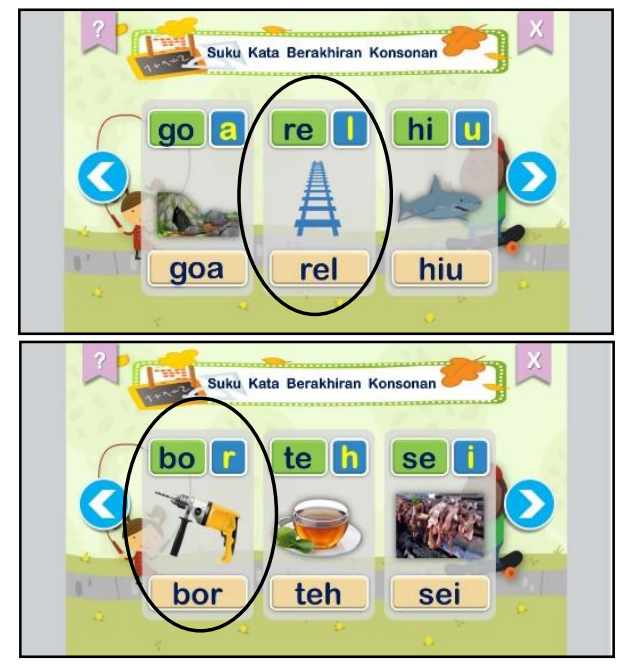

Gambar 2. Contoh Kata yang Dihapus dari Aplikasi Pembelajaran

\section{KESIMPULAN}

Produk aplikasi pembelajaran berbentuk education games berbasis budaya lokal untuk keterampilan membaca permulaan terbukti layak untuk diimplementasikan. Hal tersebut didukung dengan hasil penilaian ahli pembelajaran bahasa Indonesia SD dan praktisi terhadap tujuh aspek yang ada dalam produk aplikasi pembelajaran. Ketujuh aspek tersebut memperoleh persentase lebih dari $75 \%$. Namun, untuk aspek struktur materi perlu sedikit revisi sesuai dengan masukan ahli. Ahli pembelajaran menyebut bahwa terdapat beberapa contoh kata pada aplikasi pembelajaran yang tidak sesuai dengan kompetensi dasar sehingga perlu dihapus. Hasil uji coba terbatas yang dilakukan kepada 28 siswa kelas 1 MIN Timor Tengah Utara juga menunjukkan bahwa produk aplikasi pembelajaran yang dikembangkan layak untuk diimplementasikan. Hal tersebut didukung dengan hasil observasi kelas yang menyebut bahwa keempat aspek yang terdapat pada produk aplikasi pembelajaran memperoleh persentase nilai lebih dari $85 \%$.

\section{DAFTAR RUJUKAN}

Adhim, Mohammad. 2004. Membuat Anak Gila Membaca. Bandung: Mizan Pustaka.

Amirullah, G., \& Hardinata, R. (2017). PENGEMBANGAN MOBILE LEARNING BAGI PEMBELAJARAN. JKKP (Jurnal Kesejahteraan Keluarga Dan Pendidikan). https://doi.org/10.21009/jkkp.042.0 7

Aulina, C. N. (2016). Pengaruh Permainan Dan Penguasaan Kosakata Terhadap Kemampuan Membaca Permulaan Anak Usia 56 Tahun. PEDAGOGIA: Jurnal Pendidikan. https://doi.org/10.21070/pedagogia. v1i2.36

Fadli, Mohammad Arif. 2013. Pengembangan Aplikasi Mobile Learning Berbasis Smartphone Android untuk Pelajaran Bahasa Inggris Pokok Bahasan Recount Text. Skripsi tidak diterbitkan. Malang: Fakultas Sastra Universitas Negeri Malang.

Fithri, D. L., \& Setiawan, D. A. (2017). ANALISA DAN 
PERANCANGAN GAME EDUKASI SEBAGAI MOTIVASI

BELAJAR UNTUK ANAK USIA

DINI. Simetris: Jurnal Teknik

Mesin, Elektro Dan Ilmu Komputer. https://doi.org/10.24176/simet.v8i1. 959

Gunanto, S. G. (2018). Penciptaan

Permainan Digital Edukatif

Berbasis Wawasan Budaya Dan

Pendidikan Karakter. Journal of

Animation \& Games Studies.

https://doi.org/10.24821/jags.v2i2.1

421

Hasanudin, C., \& Puspita, E. L. (2017).

Peningkatan Motivasi dan

Keterampilan Membaca Permulaan

Siswa Kelas I Melalui Media

Aplikasi Bamboomedia BMGames

Apps. PEDAGOGIA: Jurnal

Pendidikan.

https://doi.org/10.21070/pedagogia. v6i1.618

Herman, H., Saleh, S., \& Islami, N. M.

(2017). Penerapan Media Aplikasi

Education Games Berbasis Budaya

Lokal Untuk Meningkatkan

Kemampuan Membaca Permulaan

Pada Anak di Taman Kanak-

Kanak. Seminar Nasional Lembaga

Penelitian UNM, 2(1), 481-486.

JOBAR, N. A. (2003). PENDEKATAN

DALAM PENGAJARAN

MEMBACA PERMULAAN : SATU
TINJAUAN. UNIVERSITI

PENDIDIKAN SULTAN IDRIS.

Kharisma, Giri Indra. (2019).

Pengembangan Media

Pembelajaran Berbasis Mobile

Learning untuk Memahami Teks

Prosedur bagi Siswa SMP.

Jubindo: Jurnal Ilmu Pendidikan

Bahasa dan Sastra Indonesia. 3(1).

1-9.

Pertiwi, Wahyunanda Kusuma. (2019). 2018,

Pasar Smartphone Indonesia Tumbuh

Dua Digit. Diakses pada 14 Agustus

2019,

dari https://tekno.kompas.com/read/2019

/03/01/16160037/2018-pasar-

smartphone-indonesia-tumbuh-duadigit? page $=$ all.

Rahim, F. 2008. Pengajaran Membaca di Sekolah Dasar. Jakarta: Bumi Aksara.

Ramansyah, W. (2015). Pengembangan Education Game ( Edugame )

Berbasis Android Pada Mata Pelajaran Bahasa Inggris Untuk Peserta Didik Sekolah Dasar. Jurnal Ilmiaah Edutic.

Sugiyono. 2010. Metode Penelitian Kuantitatif, Kualitatif, dan $R \& D$. Bandung: Alfabeta.

Suyitno, I. (2017). Pengembangan Pendidikan Karakter Dan Budaya Bangsa Berwawasan Kearifan Lokal. Pendidikan. 